\author{
Г.І. Лагутін ${ }^{1}$, Д.С. Цибух-Гулинський ${ }^{1}$, О.В. Сальник ${ }^{1}$, I.I. Кулинич ${ }^{2}$ \\ ${ }^{1}$ Харківський національний університет Повітряних Сил ім. І. Кожедуба, Харків \\ ${ }^{2}$ Національний університет оборони Украйни ім. I. Черняховського, Київ
}

\title{
УДОСКОНАЛЕННЯ ПРИСТРОЇВ РЕЛЕЙНОГО ЗАХИСТУ ЛІНІЙ ЕЛЕКТРОПЕРЕДАЧІ В СИСТЕМАХ ЕЛЕКТРОПОСТАЧАННЯ ВІЙСЬКОВИХ АЕРОДРОМІВ
}

\begin{abstract}
В статті проведений аналіз напрямків удосконалення пристроїв релейного захисту силових кабельних ліній систем електропостачання стаціонарних аеродромів Повітряних Сил, які залучаються для потреб проведення Операції об'єднаних сил (ООС). На підставі проведеного аналізу розглянуті функиіональні особливості мікропрочесорних пристроїв релейного захисту та системної автоматики та розроблені пропозиції щодо їх застосування для захисту високовольтних електричних мереж стачіонарних аеродромів Повітряних Сил.
\end{abstract}

Ключові слова: стачіонарний аеродром, електричні мережі, релейний захист, мікропрочесорні термінали захисту.

\section{Вступ}

Постановка проблеми. Стаття створена в рамках виконання магістерської роботи за темою “Розробка удосконалених пристроїв релейного захисту ліній електропередачі в системах електропостачання військових аеродромів, що залучаються для потреб ООС”. Для забезпечення польотів авіації в зоні проведення ООС використовуються системи електропостачання (СЕП) військових аеродромів, що живлять електроенергією відповідальних споживачів першої категорії. Порушення нормального режиму роботи СЕП може призвести до зриву виконання бойових завдань в зоні проведення ООС.

Як показує досвід проведення ООС, саме стаціонарні аеродроми можуть бути першочерговими цілями для нанесення удару, оскільки вони визначають здатність авіації виконувати поставлені завдання [1]. Силові кабельні лінії (КЛ) є важливою частиною СЕП військового аеродрому, вони мають значну протяжність, і як наслідок, суттєву вразливість від зброї дальньої дії та диверсійних груп противника.

Для швидкої локалізації зони пошкодження та захисту КЛ від пошкоджень або ненормальних режимів роботи в СЕП військових аеродромів мають використовуватися пристрої релейного захисту (Р3). Проведений аналіз показав, що для надійного захисту кабельних ліній необхідно застосовувати в комплексі декілька видів Р3: максимальний струмовий захист (МС3) або струмову відсічку (СВ) разом з захистом від замикань на землю та захистом від перевантажень [2]. В той же час, існуючі системи релейного захисту СЕП військових аеродромів виконані на застарілій елементній базі, мають високу складність та знижені показники надійності через велику тривалість експлуатації [3]. Тому виникає необхідність заміни існуючих систем Р3 на сучасні мікропроцесорні пристрої комплексного РЗ КЛ. Це дозволить підвищити надійність постачання відповідальних споживачів електричної енергії, живучість СЕП стаціонарних аеродромів, які залучаються до проведення ООС, i, як наслідок, підвищити рівень боєготовності Повітряних Сил.

Аналіз останніх досліджень і публікацій. На території військового аеродрому окремі елементи СЕП розташовані на великих відстанях один від одного. Це унеможливлює ураження всієї системи одним або навіть декількома точковими ударами, однак наявність взаємного зв'язку між складовими СЕП може призвести до швидкого поширення негативних наслідків на всю систему [4]. Як показав аналіз СЕП військових об'єктів, для забезпечення їх функціонування мають застосовуватися пристрої Р3, однак ті з них, що використовуються на даний час, в основному змонтовані понад 30 років тому та розроблені на базі електромагнітних реле. В більшості випадків вони мають обмежену працездатність у зв'язку з перевищенням гарантованого терміну експлуатації та неналежного рівня обслуговування та ремонту [5-10]. Виходячи з цього, заходи щодо відновлення існуючих пристроїв Р3 силовик КЛ СЕП стаціонарних аеродромів $€$ недоцільними.

Тому актуальним є проведення досліджень можливості використання сучасних мікропроцесорних пристроїв Р3 для забезпечення захисту силових КЛ систем електропостачання військових аеродромів від ненормальних та аварійних режимів, спрямованих на підвищення рівня надійності електропостачання. 
Мета статті - Метою роботи є дослідження можливостей застосування сучасних мікропроцесорних пристроїв РЗ для забезпечення захисту силових КЛ СЕП військових аеродромів від ненормальних та аварійних режимів, що спрямовані на підвищення рівня надійності електропостачання.

\section{Виклад основного матеріалу}

Електропостачання постійних аеродромів здійснюється, в основному, від державної енергосистеми. До складу СЕП аеродрому входять трансформаторні підстанції 10 (6)/0,4 кВ, резервні електростанції, силові кабельні лінії [11].

Силові КЛ, маючи велику довжину, зазнають пошкоджень у більшій мірі, ніж інше електричне обладнання. Вони можуть пошкоджуватися через погіршені умови охолодження, корозію оболонок кабелю, осідання грунту, а також при земляних роботах [12]. Це, а також вплив зброї та диверсійних груп противника можуть викликати короткі замикання (К3) фаз між собою і на землю. Тому для швидкого вимкнення пошкоджених ліній вони мають бути обладнані пристроями Р3.

Згідно [2], для ліній у мережах 3-10 кВ з ізольованою нейтраллю треба передбачати пристрої РЗА від багатофазних КЗ і однофазних замикань на землю. Захист має бути виконано дво- або трирелейним залежно від вимог чутливості та надійності.

На одиночних лініях з одностороннім живленням від багатофазних замикань встановлюють, як правило, двоступінчастий струмовий захист, перший ступінь якого виконано у вигляді СВ (рис. 1), а другий - у вигляді МС3 з незалежною або залежною характеристикою витримки часу (рис. 2). При цьому в електричних мережах стаціонарних військових аеродромів напругою 6 (10) кВ, які працюють з ізольованою нейтраллю, захист має діяти на вимкнення тільки від міжфазних КЗ. Замикання на землю однієї фази в таких мережах не викликає порушення роботи споживачів електричної енергії. Тому для прискорення відшукування місця пошкодження встановлюється захист $з$ дією на сигнал.

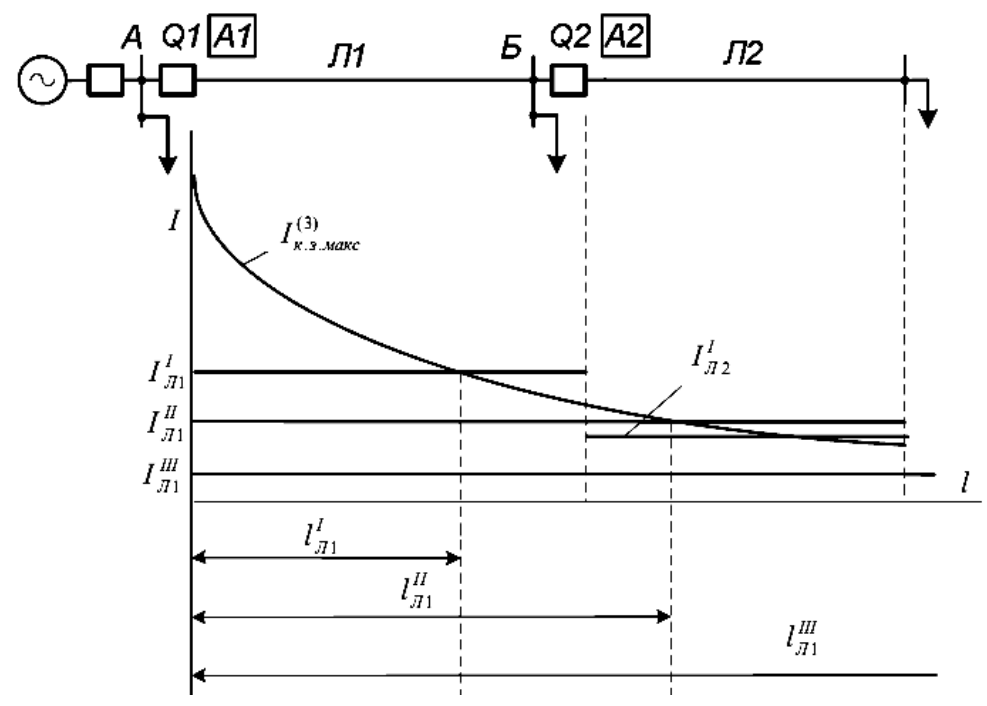

Рис. 1. Струмова відсічка в мережі з одностороннім живленням: розташування захисту та уставки струму захисту, обрані за східчастим принципом Джерело: розроблено авторами за даними [2].

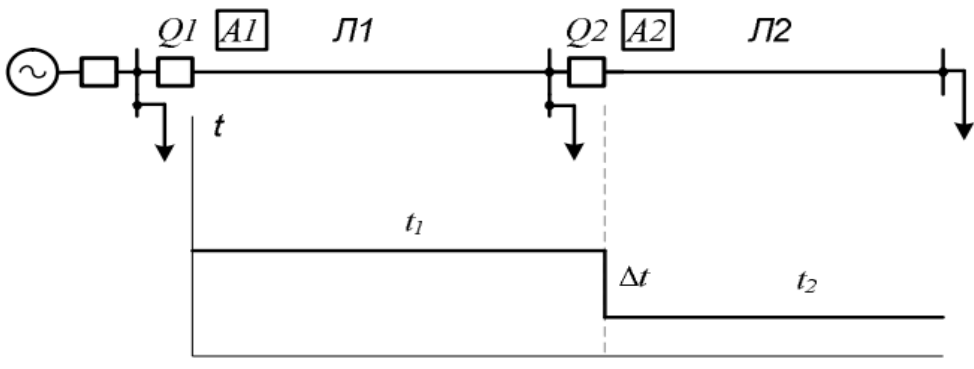

Рис. 2. Максимальний струмовий захист в мережі з одностороннім живленням: розташування захисту та витримки часу захисту, обрані за східчастим принципом Джерело: розроблено авторами за даними [2]. 
На силових КЛ з одностороннім живленням, які відходять від шин електростанцій, СВ виконують без витримки часу, а зону їх дії визначають за умови вимкнення К3, які супроводжуються залишковою напругою на шинах зазначених електростанцій, нижчою ніж 0,5-0,6 від номінальної. Для виконання зазначеної умови допускається виконувати захист неселективним у поєднанні $з$ пристроями автоматичного повторного вмикання (АПВ) або автоматичного вмикання резерву (АВР), які повністю або частково виправляють неселективну дію захисту.

Захист від однофазних замикань на землю виконується у вигляді селективного захисту (що встановлює пошкоджений напрямок), який діє на сигнал або на вимкнення, а також у вигляді пристрою контролю. Захист від однофазних замикань на землю має бути виконаним, як правило, з використанням трансфор- маторів струму нульової послідовності.

Системи Р3 електричних мереж стаціонарних аеродромів авіації Повітряних Сил містять значну кількість пристроїв Р3, побудованих на базі електромагнітних, магнітоелектричних й індукційних реле [13]. Вони достатньо складні, не забезпечують високу надійність та точність роботи, а тому потребують додаткових налаштувань і обслуговування в процесі роботи. 3 цієї точки зору доцільним є застосування мікропроцесорних систем, які відрізняються кращими масо-габаритними показниками, а також широким спектром виконуваних операцій [14-16].

Для порівняльного аналізу систем Р3 на електромагнітних та на мікропроцесорних реле розглянемо фрагмент СЕП військового аеродрому, наведений на рис. 3 , та розрахуємо струми К3, які будуть протікати в силових КЛ при КЗ в точках К1, К2.

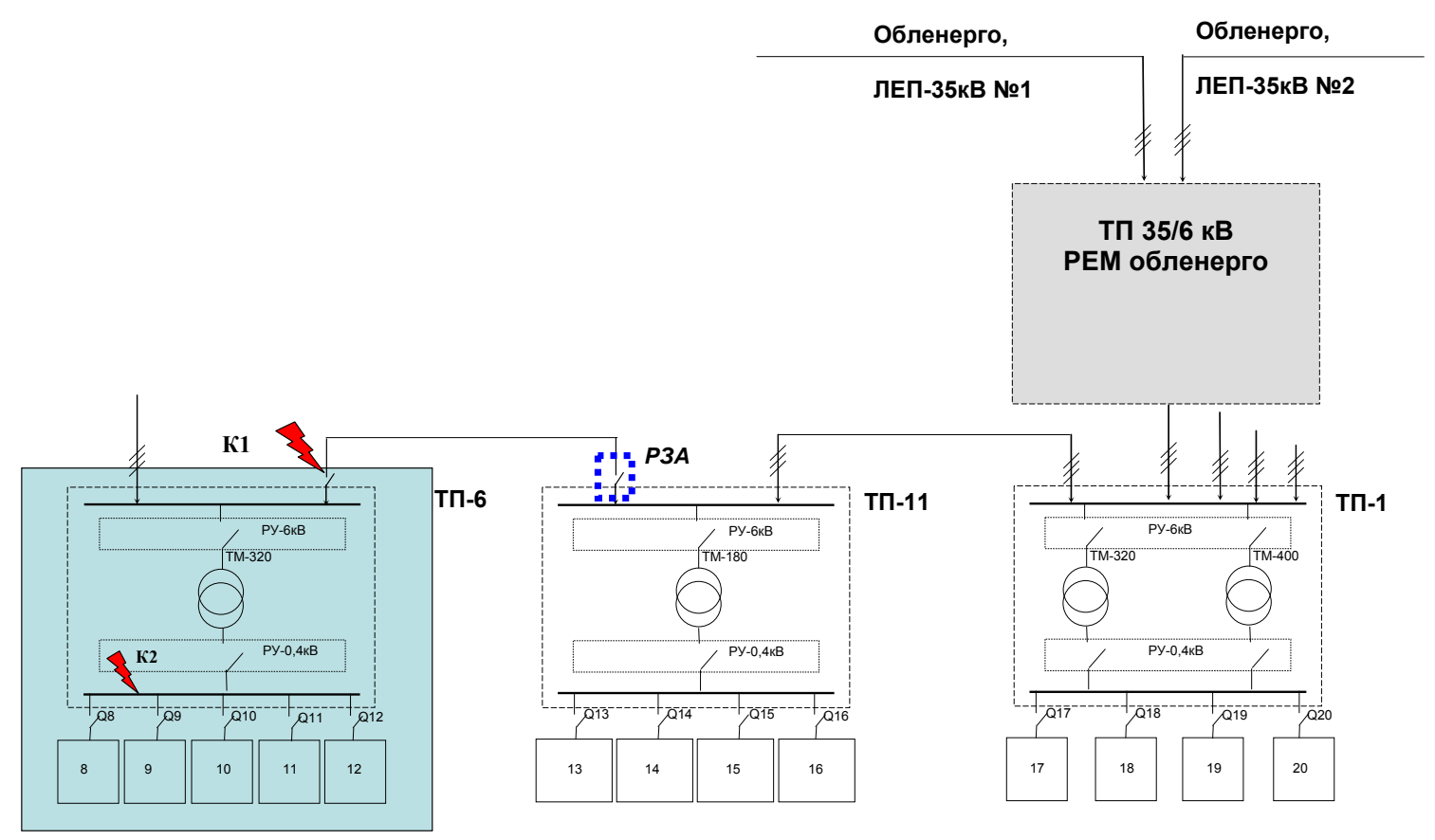

Рис. 3. Схема електропостачання військового аеродрому (фрагмент) Джерело: розроблено авторами.

Метою розрахунку струмів КЗ є визначення величин струмів у СЕП військового аеродрому в нормальних і аварійних режимах, необхідних для подальшого вибору параметрів Р3 силової КЛ. місцем встановлення пристроїв Р3 $є$ шини 6 кВ трансформаторної підстанції ТП-11. Для вибору уставок P3 необхідно розрахувати струми, які протікають в електричній мережі в нормальному режимі, а також струми КЗ: надперехідний струм $I^{\prime \prime}$, миттєве значення ударного струму $i_{y}$, i стале значення струму

$I_{\infty}$ у точці $K_{1}$. Вихідними даними для розрахунку $\epsilon$ :

ТП 35/6 кВ (система): $U_{\text {ном } 2}=6,3$ кВ, трансфо- рматор ТМ-6300/35, $I_{\kappa з с}^{3}=7,685 \kappa$ А;

КЛЕП ТП 35/6 кВ - ТП-1: кабель АСБ $3 \times 70$, $l=1440 \mathrm{M}$;

ТП-1: трансформатор ТМ-320/6, $U_{\text {ном } 3}=0,4$ кВ;

КЛ ТП-1-ТП-11: кабель СБ $3 \times 16, l=943$ м;

ТП-11: трансформатор ТМ-180/6;

КЛ ТП-11 - ТП-6: кабель СБ $3 \times 16, l=500$ м;

ТП-6: трансформатор ТМ-320/6, $U_{\text {ном } 3}=0,4$ кВ;

- завантаження трансформаторів до $55 \%$ від номінальної потужності, схема з'єднання $\Delta / \mathrm{Y}-11$;

- питомий опір алюмінію $\rho_{A l}=0,027 \mathrm{OM} \mathrm{мм}^{2} / \mathrm{M}$;

- питомий опір міді $\rho_{C u}=0,0168 \mathrm{Om} \mathrm{Mм}^{2} / \mathrm{M}$; 
- ударний коефіцієнт при КЗ на генераторних шинах $\left(X_{B H}=0\right) ; k_{y}=1,9$;

- ударний коефіцієнт в установках вище $1000 \mathrm{~B}$ $\left(\mathrm{X}_{\mathrm{BH}} \neq 0\right) \quad k_{y}=1,8$.

Визначимо струми КЗ в точці К1. В представленій однолінійній схемі СЕП для розрахунків струмів КЗ $є$ одне джерело електроенергії - державна мережа, яка характеризується величиною напруги $E$ та внутрішнім опором $x_{1}=x_{c}$, (елемент 1 на схемі заміщення, яка наведена на рис. 4).



Рис. 4. Схема заміщення

Джерело: розроблено авторами.

Елемент 2 відображає КЛ ТП 35/6 кВ - ТП-1. Елементам 3 та 4 відповідають КЛ ТП-1 ДЕС - ТП11 та КЛ ТП-11 - ТП-6 відповідно. Елементи 2 - 4 відображаються на схемі заміщення своїми індуктивними опорами.

Оскільки практично вся частина СЕП, для якої розраховуються струми короткого замикання, має єдину напругу 6,3 кВ, розрахунки ведуться в іменованих одиницях.

Опір системи визначається за виразом:

$$
x_{c}=\frac{U_{H}}{\sqrt{3} \cdot I_{K 3}^{(3)}},
$$

де $U_{H}$ - номінальна напруга в точці визначення опоpy, $\mathrm{kB}$;

$I_{\text {кз }}^{3}$ - струм трифазного КЗ у місці визначення опору, кА.

Опори КЛ будемо визначати за формулою:

$$
x_{\text {каб }}=l_{\kappa} \cdot x_{0},
$$

де $l_{\kappa}$ - довжина кабелю, км;

$x_{0}$ - номінальний опір кабелю, Ом/км.

Опори трансформаторів можливо знайти з співвідношення:

$$
x_{m p}=\frac{U_{K} \cdot U_{H}^{2}}{100 \cdot S},
$$

де $U_{\kappa}$ - напруга КЗ трансформатора, \%;
$S$ - номінальна потужність трансформатора, MBA.

Усі опори приводяться до щабля напруги, де розраховується струм К3, тобто до напруги 6,3 кВ. Перерахування опорів з високої сторони на низьку здійснюється за виразом:

$$
x_{H H}=x_{B H} \cdot\left(\frac{U_{H H}}{U_{B H}}\right)^{2} .
$$

Струм трифазного КЗ знайдемо за формулою:

$$
I_{\kappa 3}^{(3)}=\frac{U_{H}}{\sqrt{3} \cdot \sum x_{\kappa 3}} .
$$

Струм двофазного КЗ може бути обчислений на підставі величини струму трифазного КЗ: $I_{\kappa 3}^{(2)}=0,867 \cdot I_{\kappa 3}^{(3)}$. Перерахування струму з високої сторони на низьку здійснюється за виразом:

$$
I_{H н}=I_{B H} \frac{U_{B H}}{U_{H H}} .
$$

Внутрішній опір системи визначимо за заданим струмом трифазного КЗ на вторинній обмотці силового трансформатора ТМ-6300/35 підстанції ТП 35/6 кВ, від якого отримує живлення СЕП аеродрому:

$$
x_{1}=x_{c}=\frac{U_{H}}{\sqrt{3} \cdot I_{\kappa 3}^{(3)}}=\frac{6,3}{\sqrt{3} \cdot 7,685}=0,473 \text { Ом. }
$$

Для КЛ ТП 35/6 кВ - ТП-1 значення опору буде дорівнювати: $x_{2}=x_{0} \cdot \ell=0,08 \cdot 1,44=0,115$ Ом.

Для КЛ ТП-1 - ТП-11 значення опору буде дорівнювати: $x_{3}=x_{0} \cdot \ell=0,102 \cdot 0,943=0,096$ Ом.

Для КЛ ТП-11 - ТП-6 значення опору буде дорівнювати: $x_{4}=x_{0} \cdot \ell x=0,102 \cdot 0,5=0,051$ Ом.

Результуючий опір схеми буде визначатися сумою всіх опорів, що входять до схеми заміщення:

$$
x_{\text {рез }}=x_{1}+x_{2}+x_{3}+x_{4}=0,736 \text { Ом. }
$$

Надперехідний струм КЗ $I^{\prime \prime}$ не залежить від типу джерела електричної енергії й визначається лише величиною $x_{\text {рез }}$, тому його можна визначити, скориставшись виразом:

$$
I^{\prime \prime}=I_{\kappa 3}^{(3)}=\frac{U_{H}}{\sqrt{3} \cdot x_{\text {рез }}}=\frac{6,3}{\sqrt{3} \cdot 0,736}=4,941 \kappa \mathrm{A} .
$$

Ударний струм визначається 3 урахуванням ударного коефіцієнту $k_{y 1}=1,8$ за виразом:

$$
i_{y}=I^{\prime \prime} \cdot \sqrt{2} \cdot k_{y}=4,491 \cdot \sqrt{2} \cdot 1,8=11,432 \text { кА. }
$$

Стале значення струму КЗ залежить від параметрів кола й типу джерела електроенергії. Через те, що схема містить джерело необмеженої потужності, для якого діюче значення періодичної складової струму КЗ є незмінним в часі, можна записати: $I_{\infty}=I^{\prime \prime}=4,491$ кА.

Отримані значення струмів КЗ можуть бути 
використані як для вибору параметрів традиційних систем Р3, так і для налаштування мікропроцесорних терміналів Р3.

Раніше було наведено, що згідно вимог [2] для Р3 КЛ ТП-11-ТП-6 слід передбачати двоступінчастий струмовий захист від багатофазних К3, перший ступінь якого виконано у вигляді струмової відсічки, а другий - у вигляді максимального струмового захисту з незалежною або залежною характеристикою витримки часу. Крім того, має бути встановлений селективний захист від однофазних замикань на землю $з$ дією на сигнал.

Для реалізації цих пристроїв релейного захисту лінії на традиційних електромагнітних реле знадобиться принаймні 7 реле максимального струму, 2 реле часу, 3 вказівних реле та 3 проміжних реле, розташованих у відповідній шафі.

Проведений аналіз показав, що за критерієм “ціна - якість” для Р3 КЛ ТП-11 - ТП-6 доцільно використовувати найпростіші мікропроцесорні термінали релейного захисту фірми "Schneider Electric" (Франція) SEPAM серії 10. Термінал виконує всі необхідні функції релейного захисту, має розміри $180 \times 140 \times 90$ мм та вагу до 1,46 кг. Вартість одного пристрою складає близько 28 тис. грн. Застосування реле SEPAM серії 10 для захисту лінії КЛЕП ТП-11 - ТП-6 дозволяє забезпечити: захист КЛЕП від КЗ та перевантажень: СВ (реалізовується за допомогою першого ступеня МС3, код ANSI 50/51); MC3 від трифазних К3 з витримкою часу (реалізовується за допомогою другого ступеня МСЗ терміналу, код ANSI 50/51); МС3 від замикань на землю (реалізовується за допомогою МС3 нульової послідовності терміналу, код ANSI 50N/51N), тепловий захист від перевантажень (реалізовується за допомогою теплового захисту терміналу, код ANSI 49RMS). Крім цього, використання цього терміналу додатково дозволяє реалізувати такі функції, як: тимчасове зниження чутливості захисту для виключення хибного спрацьовування від пускових струмів; функція логічної селективності, яка в разі пошкодження в системі збірних шин підстанції дозволяє виконати відключення за 100 мс, при цьому забезпечується селективність фідерів (ANSI 68); дистанційне та автоматичне відключення вимикача i блокування його включення (ANSI 86); сигналізація про відключення вимикача та контроль кіл відключення; запам'ятовування 5 останніх пошкоджень в електричній мережі.

\section{Список літератури}

1. Аналіз способів та засобів щодо зниження демаскуючих чинників пересувних електростанцій в умовах ведення бойових дій / Г.І. Лагутін, В.М. Уваров, Я.А. Смола, О.О. Юр'єв // Наука і техніка Повітряних Сил Збройних Сил України. - 2020. - № 3(40). - С. 107-113. https://doi.org/10.30748/nitps.2020.40.12.

2. Правила улаштування електроустановок [Електронний ресурс]. - Х.: Форт, 2017. - 760 с. - Режим доступу: https://enext.ua/upload/books/pueh-ukraina-2017.pdf.
Перелік функцій, що виконуються мікропроцесорними терміналами Р3, наведені вище розрахунки струмів КЗ та виконані в магістерській роботі розрахунки установок спрацьовування Р3 КЛ ТП-11-ТП-6 показали можливість та доцільність застосування мікропроцесорних реле для підвищення надійності електропостачання військових аеродромів, що залучаються для потреб ООС.

\section{Висновки}

За результатами проведених досліджень устано-

1. Для забезпечення польотів авіації в зоні проведення ООС використовуються СЕП військових аеродромів, що живлять електроенергією відповідальних споживачів першої категорії. Порушення нормального режиму роботи СЕП може призвести до зриву виконання бойових завдань в зоні проведення ООС.

2. Силові КЛ $\epsilon$ важливою частиною СЕП військового аеродрому, вони мають значну протяжність, i як наслідок, суттєву вразливість від зброї дальньої дії та диверсійних груп противника. Для швидкої локалізації зони пошкодження та захисту КЛ від пошкоджень або ненормальних режимів роботи в СЕП військових аеродромів мають використовуватися пристрої Р3.

3. Згідно з вимогами керівних документів для надійного захисту кабельних ліній слід застосовувати в комплексі декілька видів Р3: МС3 або СВ разом 3 захистом від замикань на землю та захистом від перевантажень.

4. Проведений аналіз показав, що за критерієм “ціна-якість" для релейного захисту силових кабельних ліній військових аеродромів доцільно використовувати мікропроцесорні термінали релейного захисту фірми “Schneider Electric” (Франція) SEPAM серії 10.

5. Перелік функцій, що виконуються мікропроцесорними терміналами Р3, виконані розрахунки струмів КЗ та уставок спрацьовування Р3 КЛ ТП-11ТП-6 показали можливість та доцільність застосування сучасних мікропроцесорних пристроїв Р3 для забезпечення захисту силових КЛ СЕП військових аеродромів від ненормальних та аварійних режимів, що спрямовані на підвищення рівня надійності електропостачання. 
3. Лагутін Г.І. Вдосконалення способів релейного захисту силових трансформаторів в системах електропостачання військових аеродромів, що залучаються для потреб ООС / Г.І. Лагутін, А.І. Кудрявський, С.М. Хабоша // Збірник наукових праць Харківського національного університету Повітряних Сил. - 2019. - № 2(60). - С. 126-132. https://doi.org/10.30748/zhups.2019.60.16.

4. Сафронов С.П. Методичний підхід до визначення реального стану боєздатності авіації Збройних Сил України / С.П. Сафронов, М.М. Хомік, В.С. Шишкін // Наука і техніка Повітряних Сил Збройних Сил України. - 2010. № 2(4). - C. 41-45.

5. Лагутін Г.І. Застосування методу динамічного програмування для розв'язання задачі визначення оптимальної кількості джерел електричної енергії для споживачів військового аеродрому / Г.І. Лагутін, В.М. Лисенко // Наука і техніка Повітряних Сил Збройних Сил України. - 2011. - № 2(6). - С. 37-39.

6. Мурасов Р.К. Методика розрахунку імовірності успішної посадки літака / Р.К. Мурасов // Наука і техніка Повітряних Сил Збройних Сил України. - 2012. - № 3(9). - С. 53-57.

7. Лагутин Г.И. Особенности обоснования характеристик и показателей образцов электротехнических средств систем электроснабжения комплексов вооружения и военной техники / Г.И. Лагутин // Системи озброєння і військова техніка. - 2015. - № 4(44). - С. 21-23.

8. Моніторинг станів операційного середовища та багатоструктурних систем військового призначення при управлінні їх функціонуванням та структурною динамікою / Д.А. Гриб, Б.О. Демідов, Ю.Ф. Кучеренко, О.Г. Матющенко, О.О. Хмелевська // Збірник наукових праць Харківського національного університету Повітряних Сил. - 2019. № 1(59). - C. 14-25. https://doi.org/10.30748/zhups.2019.59.02.

9. Буданов П.Ф. Повышение надёжности функционирования энергообъектов на основе усовершенствования программно-технического комплекса автоматизированной подсистемы аварийной и предупредительной защиты / П.Ф. Буданов, К.Ю. Бровко, П.В. Васюченко // Збірник наукових праць Харківського національного університету Повітряних Сил. - 2016. - № 3(48). - С. 161-167.

10. Нор П.І. Методика оцінки технічного рівня зразків озброєння та військової техніки / П.І. Нор, П.В. Щипанський, С.Ю. Гогонянц // Системи озброєння і військова техніка. - 2014. - № 3(39). - С. 49-53.

11. Мушаров А.О. Аналіз засобів функціонального ураження електротехнічних засобів комплексів озброєння та військової техніки / А.О. Мушаров // Збірник наукових праць Харківського національного університету Повітряних Сил. - 2011. - № 3(29). - С. 186-189.

12. Буданов П.Ф. Моделювання ознак аварійності параметрів технологічного процесу об'єктів електроенергетики / П.Ф. Буданов, К.Ю. Бровко // Збірник наукових праць Харківського національного університету Повітряних Сил. 2015. - № 2(43). - С. 84-88.

13. Герасимов С.В. Розробка оптимальної методики контролю параметрів технічних систем за критерієм точності / С.В. Герасимов // Збірник наукових праць Харківського національного університету Повітряних Сил. - 2014. № 1(38). - С. 213-216.

14. Офіційний сайт SE.COM. Реле Sepam серії 10. - Режим доступу: https://www.se.com/ua/ru/productsubcategory $/ 4735$-sepam-\%D1\%81\%D0\%B5\%D1\%80\%D0\%B8\%D0\%B9-10/.

15. Офіційний сайт RELSIS.UA. Мікропроцесорні пристрої релейного захисту та автоматики для об'єктів енергетики 6-35-110 кВ. - Режим доступу: https://relsis.ua/ua/products/relay-protection-automation.

16. Офіційний сайт EDS-POWER.COM. Пристрої і термінали PЗА. - Режим доступу: https://eds-power.com/rzia.

Надійшла до редколегії 14.03.2021

Схвалена до друку 12.05.2021

\section{Відомості про авторів:}

\section{Лагутін Геннадій Іванович}

кандидат технічних наук доцент

начальник кафедри

Харківського національного університету

Повітряних Сил ім. І. Кожедуба,

Харків, Україна

https://orcid.org/0000-0002-6337-1357

\section{Цибух-Гулинський Дмитро Сергійович}

курсант

Харківського національного

університету Повітряних Сил ім. І. Кожедуба,

Харків, Україна

https://orcid.org/0000-0003-3860-0426

\section{Information about the authors:}

Hennadiy Lahutin

Candidate of Technical Sciences Associate Professor

Head of Department

of Ivan Kozhedub Kharkiv

National Air Force University,

Kharkiv, Ukraine

https://orcid.org/0000-0002-6337-1357

\author{
Dmitry Tsibukh-Gulinsky \\ Cadet \\ of Ivan Kozhedub Kharkiv \\ National Air Force University, \\ Kharkiv, Ukraine \\ https://orcid.org/0000-0003-3860-0426
}


Сальник Олег Вікторович старший науковий співробітник науково-дослідної лабораторії Харківського національного університету Повітряних Сил ім. І. Кожедуба, Харків, Україна https://orcid.org/0000-0002-2688-1198

\section{Кулинич Ігор Ігорович}

старший науковий співробітник науково-дослідного відділу центру імітаційного моделювання Національного університету оборони України ім. І. Черняховського, Київ, Україна https://orcid.org/0000-0001-5543-842X
Oleh Sal'nyk

Senior Research Associate of Scientific Research Laboratory

of Ivan Kozhedub Kharkiv

National Air Force University,

Kharkiv, Ukraine

https://orcid.org/0000-0002-2688-1198

\section{Igor Kulinich}

Senior Research Associate of Scientific Research Department of Simulation Center of Ivan Chernyakhivsky National University of Defense of Ukraine, Kyiv, Ukraine https://orcid.org/0000-0001-5543-842X

\title{
СОВЕРШЕНСТВОВАНИЕ УСТРОЙСТВ РЕЛЕЙНОЙ ЗАЩИТЫ ЛИНИЙ ЭЛЕКТРОПЕРЕДАЧИ В СИСТЕМАХ ЭЛЕКТРОСНАБЖЕНИЯ ВОЕННЫХ АЭРОДРОМОВ
}

\author{
Г.И. Лагутин, Д.С. Цибух-Гулинский, О.В. Сальник, И.И. Кулинич
}

В статье проведен анализ направлений совершенствования устройств релейной защиты силовых кабельных линий систем электроснабжения стационарных аэродромов Воздушных Сил, привлекаемых для нужд проведения Операции объединенных сил. На основании проведенного анализа рассмотрены функциональные особенности микропроцессорных устройств релейной защиты и системной автоматики и разработаны предложения по их применению для защзиты высоковольтных электрических сетей стационарных аэродромов Воздушных Сил.

Ключевые слова: стационарный аэродром, электрические сети, релейная защита, микропроцессорные терминальз защиты, молекулярный накопитель энергии.

\section{IMPROVEMENT OF RELAY PROTECTION DEVICES FOR POWER TRANSMISSION LINES IN POWER SUPPLY SYSTEMS OF MILITARY AIRFIELDS INVOLVED}

H. Lahutin, D. Tsibukh-Gulinsky, O. Sal'nyk, I. Kulinich

Electrical networks of military airfields, which are used during the Joint Forces operation, have a significant length, and as a result, significant vulnerability to long-range weapons and enemy sabotage groups. Relay protection and automation of electrical networks is the only way that allows quick localization of damage and, as a result, ensure the operation of the power supply system. Relay protection devices used today, in most cases, have limited performance due to exceeding the guaranteed service life and inadequate level of maintenance and repair. Therefore, it is relevant to conduct research aimed at the introduction of integrated devices for microprocessor relay protection. This will increase the survivability of the power supply systems of stationary airfields, the reliability of supply to responsible consumers of electrical energy, and, as a consequence, increase the level of Air Force combat readiness. The article discusses the possibilities of using modern relay protection devices, built on the basis of microprocessor terminals, to ensure the protection of power cable lines of military airfields power supply systems. The analysis of the requirements of the governing documents showed that two-stage current protection should be used to protect power cable lines, the first stage of which is made in the form of a current cutoff, and the second - in the form of overcurrent protection. The article compares two options for building a relay protection system. Calculations of short-circuit currents and settings for the operation of relay protection of power cable lines of military airfields have shown the possibility and expediency of using microprocessor relays to improve the reliability of power supply to military airfields.

Keywords: stationary airfield, electrical networks, relay protection, microprocessor protection terminals. 